\title{
Gataparsen Sodium
}

National Cancer Institute

\section{Source}

National Cancer Institute. Gataparsen Sodium. NCI Thesaurus. Code C66935.

A second-generation antisense oligonucleotide ag ainst survivin mRNA with potential antitumor activity. Gataparsen hybridizes to survivin mRNA, thereby blocking translation of survivin protein, a member of the inhibitor of apoptosis (IAP) family. Survivin, expressed during embryonal development, is upregulated in a variety of human cancers while absent in most normal adult cells; its expression in tumors is associated with a more aggressive phenotype, shorter survival times, and a decreased response to chemotherapy. Silencing expression of survivin potentially leads to restoration of the apoptotic process in cancer cells, thereby facilitating chemotherapeutic treatments. 